\title{
Resident memory T cells, critical components in tumor immunology
}

\author{
Fathia Mami-Chouaib ${ }^{*}$, Charlotte Blanc ${ }^{2,3,4 \dagger}$, Stéphanie Corgnac ${ }^{1 \dagger}$, Sophie Hans ${ }^{2,3,4}$, Ines Malenica', \\ Clémence Granier ${ }^{2,3,4}$, Isabelle Tihy ${ }^{1}$ and Eric Tartour ${ }^{2,3,4^{*}}$
}

\begin{abstract}
$\mathrm{CD}^{+} \mathrm{T}$ lymphocytes are the major anti-tumor effector cells. Most cancer immunotherapeutic approaches seek to amplify cytotoxic $T$ lymphocytes (CTL) specific to malignant cells. A recently identified subpopulation of memory $\mathrm{CD}^{+} \mathrm{T}$ cells, named tissue-resident memory $\mathrm{T}\left(\mathrm{T}_{\mathrm{RM}}\right)$ cells, persists in peripheral tissues and does not recirculate. This T-cell subset is considered an independent memory T-cell lineage with a specific profile of transcription factors, including Run $\times 3^{+}, \mathrm{Notch}^{+}, \mathrm{Hobit}^{+}, \mathrm{Blimp}^{+}, \mathrm{BATF}^{+}, \mathrm{AHR}^{+}, \mathrm{EOMES}^{\text {neg }}$ and Tbet ${ }^{\text {low }}$. It is defined by expression of CD103 $\left(a_{E}(C D 103) \beta_{7}\right)$ and CD49a (VLA-1 or $\left.a_{1} \beta_{1}\right)$ integrins and C-type lectin CD69, which are most likely involved in retention of $T_{\text {RM }}$ cells in non-lymphoid tissues, including solid tumors. CD103 binds to the epithelial cell marker E-cadherin, thereby favoring the location and retention of $\mathrm{T}_{\mathrm{RM}}$ in epithelial tumor regions in close contact with malignant cells. The CD103-E-cadherin interaction is required for polarized exocytosis of lytic granules, in particular, when ICAM-1 expression on cancer cells is missing, leading to target cell death. $T_{\text {RM }}$ cells also express high levels of granzyme B, IFNY and TNFa, supporting their cytotoxic features. Moreover, the local route of immunization targeting tissue dendritic cells (DC), and the presence of environmental factors (i.e. TGF- $\beta$, IL-33 and IL-15), promote differentiation of this T-cell subtype. In both spontaneous tumor models and engrafted tumors, natural $T_{R M}$ cells or cancer-vaccine-induced $T_{\text {RM }}$ directly control tumor growth. In line with these results, $T_{R M}$ infiltration into various human cancers, including lung cancer, are correlated with better clinical outcome in both univariate and multivariate analyses independently of $\mathrm{CD}^{+} \mathrm{T}$ cells. $\mathrm{T}_{\mathrm{RM}}$ cells also predominantly express checkpoint receptors such as PD-1, CTLA-4 and Tim-3. Blockade of PD-1 with neutralizing antibodies on $T_{R M}$ cells isolated from human lung cancer promotes cytolytic activity toward autologous tumor cells. Thus, $T_{R M}$ cells appear to represent important components in tumor immune surveillance. Their induction by cancer vaccines or other immunotherapeutic approaches may be critical for the success of these treatments. Several arguments, such as their close contact with tumor cells, dominant expression of checkpoint receptors and their recognition of cancer cells, strongly suggest that they may be involved in the success of immune checkpoint inhibitors in various cancers.
\end{abstract}

Keywords: Resident memory T cells, Immune checkpoint receptors, Immunotherapy, CD103 integrin, Immunosurveillance

\footnotetext{
* Correspondence: fathia.mami-chouaib@gustaveroussy.fr; fathia.mami-

chouaib@inserm.fr; eric.tartour@aphp.fr

${ }^{\dagger}$ Charlotte Blanc and Stéphanie Corgnac contributed equally to this work.

${ }^{1}$ INSERM UMR 1186, Integrative Tumor Immunology and Genetic Oncology,

Gustave Roussy, EPHE, PSL, Faculté de Médecine, University Paris-Sud,

Université Paris-Saclay, 39, rue Camille Desmoulins, F-94805 Villejuif, France

${ }^{2}$ INSERM U970, Universite Paris Descartes, Paris, France

Full list of author information is available at the end of the article
}

(c) The Author(s). 2018 Open Access This article is distributed under the terms of the Creative Commons Attribution 4.0 International License (http://creativecommons.org/licenses/by/4.0/), which permits unrestricted use, distribution, and

reproduction in any medium, provided you give appropriate credit to the original author(s) and the source, provide a link to the Creative Commons license, and indicate if changes were made. The Creative Commons Public Domain Dedication waiver (http://creativecommons.org/publicdomain/zero/1.0/) applies to the data made available in this article, unless otherwise stated. 


\section{Background}

Conventional memory $\mathrm{T}$ cells classically include central memory $\mathrm{T}\left(\mathrm{T}_{\mathrm{CM}}\right)$ cells, residing in lymphoid organs and reactivated during secondary infection, and effector memory $\mathrm{T}\left(\mathrm{T}_{\mathrm{EM}}\right)$ cells, circulating through various tissues and endowed with cytotoxic properties. A population of memory $\mathrm{T}$ cells, named tissue resident memory $\mathrm{T}\left(\mathrm{T}_{\mathrm{RM}}\right)$ cells, has been recently identified. These memory $\mathrm{T}$ cells persist in tissues and do not recirculate [1-6]. A seminal work from Klonowski et al. showed limited mixing of blood $\mathrm{CD}^{+} \mathrm{T}$ lymphocytes with intraepithelial lymphocytes (IEL) from the lamina propria and the brain between mice joined by parabiosis [7]. Then, D Masopust in the group of $\mathrm{R}$ Ahmed demonstrated the residency of intestinal memory $\mathrm{CD}^{+}{ }^{+} \mathrm{T}$ cells after transplantation of gut harboring memory $\mathrm{CD}^{+} \mathrm{T}$ cells into naive mice [8] and Steinert et al., by parabiosis experiments [9]. These cells appear to be generated from a subpopulation of $\mathrm{T}_{\mathrm{EM}}$ cells patrolling and surveying the tissue. $\mathrm{T}_{\mathrm{CM}}$ cells have also the ability to differentiate into $\mathrm{T}_{\mathrm{RM}}$ cells after reactivation and acquisition of CD69 molecule leading to retention in the tissue [10]. A body of evidence has shown that $T_{R M}$ cells represent an independent memory $\mathrm{T}$-cell lineage with a specific differentiation pathway. Unexpectedly, transcription factors that have usually been associated with long-lived memory cells, such as eomesodermin (EOMES) and transcription factor 1 (TCF1, also known as HNF1 $\alpha$ ) [11, 12], are not expressed in $\mathrm{T}_{\mathrm{RM}}$ cells. In mice, but not in humans, the combined loss of Hobit and Blimp-1 transcription factors strongly compromised development of $\mathrm{T}_{\mathrm{RM}}[13,14]$. Recent studies identified Notch and Runx3 transcription factors as master regulators in induction and maintenance of human $\mathrm{CD}^{+} \mathrm{T}_{\mathrm{RM}}$ cells $[14,15]$. Accessible chromatin regions were identified in IEL mature TRM cells near genes characteristically expressed in mature TRM cells (such as $C d 69$ and $N r 4 a 1$ ), whereas genes that promote T-cell recirculation (such as Klf2 and S1pr1) exhibited loss of accessible regions [14, 15]. The latter study also demonstrated that $\mathrm{CD}^{+}{ }^{+} \mathrm{T}$ cells localized in non-lymphoid tissues have a global chromatin landscape that differed from that of lymphoid effector $\mathrm{CD}^{+} \mathrm{T}$ cells, reinforcing the unique features of the $\mathrm{T}_{\mathrm{RM}}$ cell subset [15]. The cytokines interleukin-33 (IL-33) and tumor necrosis factor (TNF), in combination with TGF- $\beta$, can induce a $\mathrm{T}_{\mathrm{RM}}$ cell-like phenotype [16], as well as downregulation of KLF2 expression in $\mathrm{CD} 8^{+} \mathrm{T}$ cells [17]. KLF2 promotes expression of genes such as sphingosine-1-phosphate receptor 1 (S1PR1), favoring the egress of $\mathrm{T}$ cells from tissues [17].

$\mathrm{T}_{\mathrm{RM}}$ cells play an essential role in protecting human epithelial tissues against infectious and inflammatory diseases. They are highly activated $\mathrm{T}$ lymphocytes that reside within a variety of peripheral tissues, including intestine $[8,18]$, brain $[19]$, skin $[3,20]$ and lung $[21]$, and they provide rapid and effective responses to viral reinfections [22]. This T-cell subset is defined by expression of CD103 $\left(\alpha_{E}(C D 103) \beta_{7}\right)$ and CD49a (VLA-1 or $\left.\alpha_{1} \beta_{1}\right)$ integrins and the C-type lectin CD69. This phenotype may explain the retention of $\mathrm{T}_{\mathrm{RM}}$ cells in tissue. Indeed, a role for CD103 in T-cell homing into epithelia has been previously suggested [23-25]. Along the same lines, an enhanced $\mathrm{CD}_{103^{+}}$TIL subset correlated with increased intraepithelial lymphocyte infiltration [26, 27], supporting the hypothesis that CD103 promotes recruitment of $T_{R M}$ cells within epithelial tumor islets. The intra-epithelial location of $\mathrm{CD} 103^{+} \mathrm{CD}^{+} \mathrm{T}$ cells was also observed in colorectal and bladder cancers, and was associated with expression of E-cadherin on tumor cells $[28,29]$. Consistently, studies performed with viable human tumor slices [30] and autologous tumor antigen-specific CTL clones showed that CD103 contributes to T-cell recruitment within epithelial tumor regions and enhances intratumoral $\mathrm{T}$-cell early signaling [31]. Indeed, recruitment of $\mathrm{CD}^{+} \mathrm{T}$ lymphocytes within epithelial tumor islets was inhibited by anti-CD103 neutralizing monoclonal antibodies (mAb), while TGF- $\beta$ enhanced CD103-dependent T-cell movement toward epithelial tumor regions [31]. In this context, studies from one of our groups showed that CD103 mediates arrest of T lymphocytes under flow by interacting with E-cadherin on epithelial tumors [32]. Moreover, interaction of CD103 with E-cadherin promotes CCR5 recruitment at the immune synapse formed between $\mathrm{T}_{\mathrm{RM}}$ cells and tumor target cells, leading to inhibition of T-cell sensitivity to the CCL5 chemotactic gradient [33].

CD49a is not required for initial recruitment of effector $\mathrm{CD}^{+} \mathrm{T}$ cells, but is critically important in their retention during the memory phase [34, 35]. We and other groups have shown that the number of $T_{R M}$ cells is reduced in peripheral tissues after injection of anti-VLA-1 blocking antibodies at the memory phase of the immune response [34], as well as in tumors [36]. The CD69 molecule downregulates expression of S1PR1, which favors the exit of $\mathrm{T}$ cells from tissues [37]. Intra-tumoral $\mathrm{CD}^{+} \mathrm{T}_{\mathrm{RM}}$ cells express high levels CD69 and concomitantly low levels of S1PR1, which prevent their recirculation in the bloodstream and their migration into lymphoid organs $[17,38]$. Moreover, parabiosis experiments demonstrated that $T_{R M}$ cells induced after therapeutic cancer vaccination were unable to migrate toward the non-immunized parabiont, supporting their tissue residency features [39]. It is noteworthy that some $\mathrm{CD} 8^{+} \mathrm{T}_{\mathrm{RM}}$ cells lack $\mathrm{CD} 103$, and that this integrin is not an absolute marker for residency of $\mathrm{CD}^{+} \mathrm{T}_{\mathrm{RM}}[40,41]$. For example, $\mathrm{CD}^{+}$memory $\mathrm{T}$ cells in human dermis lack CD103 expression, whereas those in the epidermis are $\mathrm{CD}_{103^{+}}$[42]. Notably, the presence of $\mathrm{T}_{\mathrm{RM}}$ cells in human epithelial tumors and the role of this $\mathrm{T}$-cell subset in anti-tumor immunity 
have thus far not been systematically addressed. Accumulating evidence indicates that $\mathrm{T}_{\mathrm{RM}}$ cells also frequently reside in human tumors, especially of epithelial origin, and play an essential role in tumor-specific T-cell responses (for a review see [43]).

\section{Phenotypic features of $T_{R M}$ cells in cancer}

Previous studies from one of our groups revealed that human lung tumor-infiltrating lymphocytes (TIL) include a homogeneous $\mathrm{CD}^{+}$T-cell population defined by expression of CD103 and CD69 [27]. $\mathrm{T}_{\mathrm{RM}}$ cells do not express CCR7, CD62L or S1PR1 [14, 27, 38], which are required for tissue exit (Fig. 1). This $\mathrm{CD} 103^{+} \mathrm{CD} 8^{+}$ T-cell subset displays a unique transcriptomic signature characteristic of $\mathrm{T}_{\mathrm{RM}}$ cells, with upregulation of retention and adhesion-molecule-encoding genes such as RGS1, RGS2, ITGA1, ITGAV and VCAM1 [14, 27]. This TIL subpopulation also expresses a broad range of chemokine receptors, including CXCR3, CCR5 and CCR6, and was able to produce chemokines such as CCL3, CCL4, CCL5, and inflammatory cytokines such as IFN $\gamma$ and TNF. $\mathrm{T}_{\mathrm{RM}}$ cells also express the pro-survival family member $\mathrm{Bcl}-2$, as well as anti-apoptotic factors, including PHLDA1 and BIRC3, which may explain their long survival in tissues $[14,27]$.

Furthermore, there is a cluster of transcription factors associated with $\mathrm{T}_{\mathrm{RM}}$. These factors include activator protein AP-1, Notch1-RBPJ (RBPJ is also known as CSL) and NF- $\mathrm{kB}$ transcription factor complexes, as well as BATF (basic leucine zipper transcription factor) and AHR (aryl hydrocarbon receptor), which regulate expression of homing receptors and maintenance of mouse $\mathrm{T}_{\mathrm{RM}}$ cells, respectively [38, 44, 45]. BATF has also been shown to regulate the metabolism and survival of $\mathrm{CD}^{+} \mathrm{T}$ cells $[46,47]$. Residual Tbet expression in $\mathrm{T}_{\mathrm{RM}}$ promotes expression of IL-15R, which is critical for $T_{R M}$ survival and functions [48]. However, overexpression of Tbet transcription factor inhibits the generation of $T_{R M}$ cells. Remarkably, human infant $\mathrm{T}$ cells exhibit increased expression of Tbet compared with adult $\mathrm{T}$ cells, leading to a preferential generation of effector $\mathrm{T}$ cells over $\mathrm{T}_{\mathrm{RM}}$ cells $[49,50]$. This data may explain that infants suffer disproportionately from respiratory infections.

NAB1 is a transcription factor overexpressed in $T_{R M}$ cells, the mouse homolog of which (NAB2) is induced in $\mathrm{CD}^{+} \mathrm{T}$ cells that have received help from $\mathrm{CD} 4^{+} \mathrm{T}$ cells, and is needed to prevent activation-induced cell death (AICD) of those 'helped' CD8 ${ }^{+} \mathrm{T}$ cells [51]. $\mathrm{T}_{\mathrm{RM}}$ also exhibited a glucose-deprivation signature, consistent with a lower glucose concentration in airway fluid than in blood. In lung cancer, $\mathrm{T}_{\mathrm{RM}}$ cells had elevated expression of genes related to hypoxia, such as HIF1A (which encodes HIF-1 $\alpha$ ) and EPAS1 (which encodes HIF-2 $\alpha$ ) [14].

\section{Mechanisms of action of $\mathrm{T}_{\mathrm{RM}}$ cells Role of CD103 integrin}

CD103 integrin is a heterodimeric transmembrane receptor formed by $\alpha_{\mathrm{E}}(\mathrm{CD} 103)$ and $\beta_{7}$ subunits, with the epithelial cell marker E-cadherin as a unique known
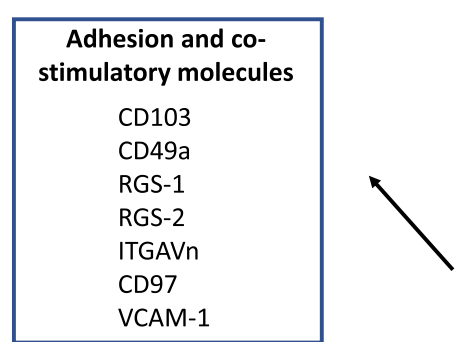

E-cadherin

\begin{tabular}{|l|}
\hline Transcription factors \\
Notch-RBPJ \\
Runx3 \\
Hobit \\
Blimp1 \\
BATF \\
AHR \\
Nab1 \\
HIF \\
\hline
\end{tabular}

Tumor cells

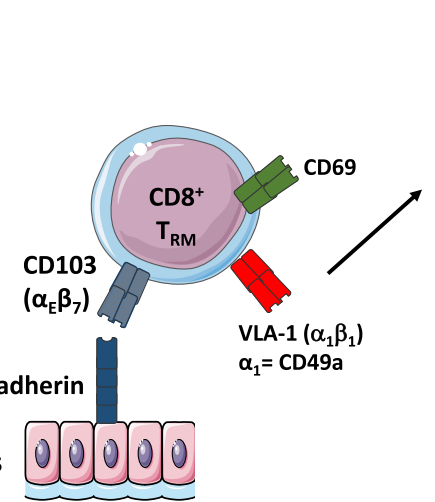

\begin{tabular}{|c|}
\hline $\begin{array}{c}\text { Activation and } \\
\text { cytotoxic markers }\end{array}$ \\
Ki67 \\
HLA-DR \\
Granzyme B \\
TIA-1 \\
IFN $\gamma$ \\
TNF \\
\hline
\end{tabular}

Fig. 1 Core signature of resident memory T cells. Results from transcriptomic and cytometry analyses define some core markers belonging to family of molecules (adhesion/costimulatory molecules, chemokines and chemokine receptors, activation and cytotoxic markers, and transcription factors, etc.). However, the phenotype of $\mathrm{T}_{\mathrm{RM}}$ cells may vary depending on their location 
ligand [52]. This integrin is expressed on $\mathrm{T}$ cells residing in tissue microenvironments, where TGF- $\beta$ is abundant, such as mucosal $\mathrm{CD} 8^{+} \mathrm{T}$ lymphocytes and, mainly, IEL [53], but it is also expressed on $\mathrm{CD}^{+}$and $\mathrm{CD}^{+}$regulatory $\mathrm{T}$ (Treg) cells $[54,55]$ and on a large proportion of $\mathrm{CD}^{+}$effector $\mathrm{T}$ cells infiltrating epithelial tumors, including bladder [56], pancreatic [57], colorectal [28], ovarian [26] and lung cancers [27, 38, 58, 59]. It is induced on tumor-specific $\mathrm{CD} 8^{+} \mathrm{T}$ cells by concomitant signals from the TGF- $\beta$ receptor (TGFBR) and the T-cell receptor (TCR) triggered by TGF- $\beta$ and major histocompatibility complex class I (MHC-I)/tumor peptide complexes, respectively (Fig. 2) [33, 58, 60]. In this regard, adoptive transfer of tumor-specific $\mathrm{CD} 8^{+} \mathrm{CD} 103^{+-} \mathrm{T}$ cells in the cognate tumor engrafted in nonobese diabetic/severe combined immunodeficient (NOD/SCID) mice and subsequent coengagement of TCR and TGFBR trigger CD103 expression on T-cell surface associated with acquisition of a strong cytotoxic capacity toward autologous tumor cells. In contrast, adoptive transfer of these $\mathrm{CD}^{+} \mathrm{CD} 103^{-} \mathrm{T}$ cells in allogeneic tumor does not result in expression of CD103 $[33,58]$. Along the same line, CD103 is induced on tumor-specific $\mathrm{T}$ cells upon engagement of TCR with anti-CD3 $\mathrm{mAb}$ and TGF- $\beta$ treatment $[58,60,61]$. In contrast, TGF- $\beta$ alone had only a slight effect on CD103 expression and anti-CD3 mAb alone had no effect [58]. It is well known that only 1 to $3 \%$ of human circulating $\mathrm{T}$ cells expressed CD103, which implies that tumor-specific $T$ cells need to encounter the cognate antigen within a TGF- $\beta$-rich tumor microenvironment to induce expression of the integrin and to become $\mathrm{T}_{\mathrm{RM}}$.

CD103 appears to be a key molecule in T-cell activation and functions within the tumor microenvironment. Accordingly, a correlation between the expression level of CD103 on tumor-specific T-cell clones, stimulated in vitro with IL-2 and irradiated autologous tumor cells, and their capacity to kill autologous E-cadherin ${ }^{+}$tumor cells was observed [58]. Indeed, CD103 is recruited at the immune synapse formed between CTL and epithelial tumor cells, and its interaction with E-cadherin is required for polarized exocytosis of lytic granules, leading to target cell lysis (Fig. 2). Moreover, killing of target cells was abrogated by anti-CD103 neutralizing mAb and siRNA targeting E-cadherin, pointing to a major role for the CD103-E-cadherin interaction in the anti-tumor CTL response. CD103 also helps in secretion of cytokines by tumor-specific CTL by interacting with E-cadherin on target cells [32]. This integrin is essential in controlling $\mathrm{CD}^{+}$TIL activities, not only by promoting effector T-cell adhesion to tumor cells, but also by triggering intracellular

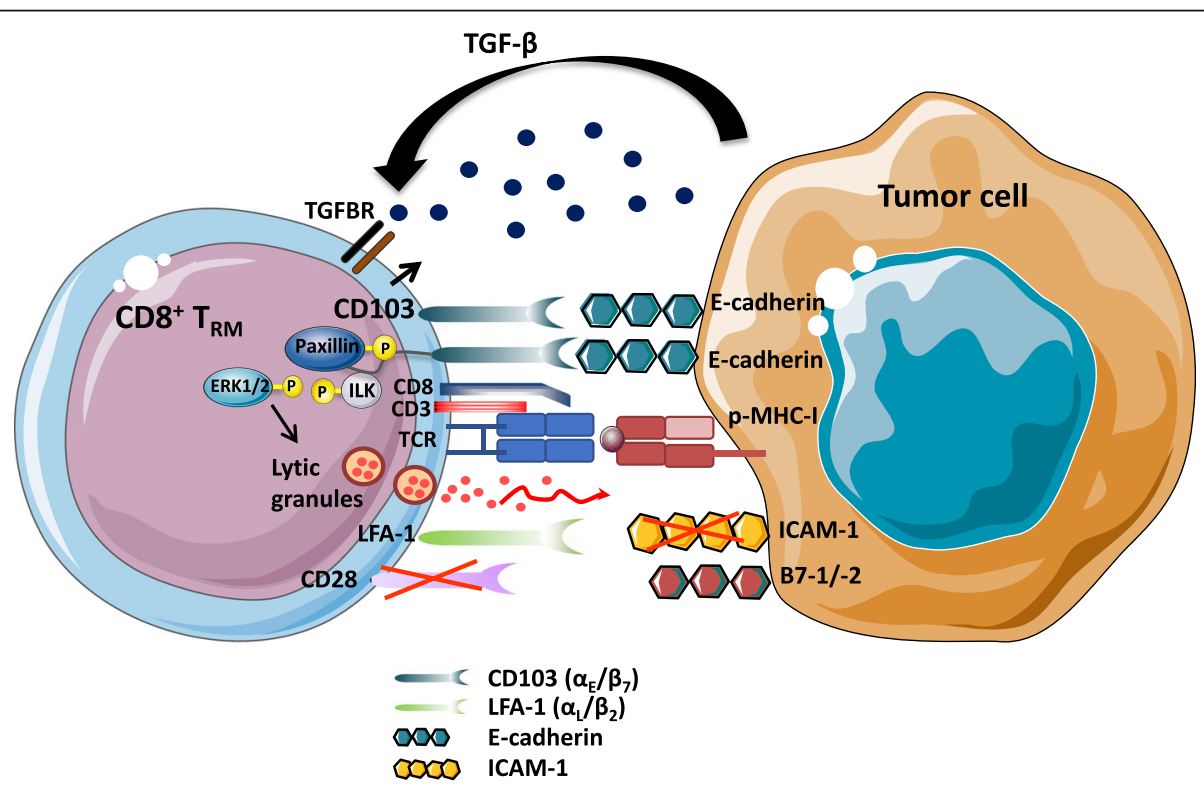

Fig. 2 Role of CD103 integrin in anti-tumor $T_{\text {RM }}$ functional activities. Engagement of TCR with specific peptide-MHC-I ( $\left.p-M H C-I\right)$ complexes in the presence of TGF- $\beta$, abundant within the tumor microenvironment, induces expression of CD103 on the CD8 ${ }^{+}$T-lymphocyte surface. Phosphorylation of integrin-linked kinase (ILK) by TGFBR1, and its subsequent binding to the CD103 intracellular domain promotes inside-out signaling resulting in an increase in the affinity of the integrin for its ligand E-cadherin on tumor cells. Activated CD103 is recruited at the immune synapse formed between stimulated $T_{R M}$ cells and epithelial target cells; its interaction with E-cadherin triggers phosphorylation of extracellular signal-regulated kinases 1 and 2 (ERK1/2) and the paxillin adaptor protein. Binding of phosphorylated (p)-paxillin to the $a_{E}$ (CD103) subunit tail triggers an outside-in signal that promotes $C D 8^{+}$T-cell effector functions such as cytokine production and polarized release of cytotoxic granules, leading to TCR-mediated target cell death. Intra-tumoral $T_{R M}$ cells express very low levels of CD28 co-stimulatory receptor. Moreover, expression of LFA-1 on TIL is downregulated by TGF- $\beta$. Finally, cancer cells often downregulate expression of the LFA-1 ligand ICAM-1 to escape from immune effector cells 
signaling events that co-stimulate TCR signals [59]. Indeed, binding of CD103 on freshly isolated tumor-infiltrating $\mathrm{CD}^{+} \mathrm{T}_{\mathrm{RM}}$ cells to immobilized recombinant E-cadherin-FC is sufficient to induce re-localization of cytolytic granules at the contact area, while degranulation requires TCR co-engagement. Moreover, this minimal triggering of CD103 promotes phosphorylation of ERK1/2 and phospholipase C (PLC) $\gamma 1$, resulting in granule polarization and hence TCR-mediated cytotoxicity.

Activation of integrins on $\mathrm{T}$ cells is regulated by "inside-out" signaling, initiated by TCR and chemokine receptor stimulation, inducing integrin-extended conformation and clustering, thereby increasing their affinity for their ligands [62]. Remarkably, data from one of our groups indicated that TGF- $\beta$ not only participates in CD103 induction on TCR-engaged antigen-specific $\mathrm{CD}^{+} \mathrm{T}$ cells $[33,58,60]$, but is also directly involved in CD103 activation (Fig. 2). Indeed, TGF- $\beta$ triggers TGFBR1-mediated phosphorylation of ILK and its subsequent binding to the integrin intracellular domain, resulting in AKT phosphorylation and thereby initiating inside-out signaling that leads to increased CD103 affinity for its ligand E-cadherin [31]. Firm adhesion of CD103 to E-cadherin triggers phosphorylation of Pyk2 protein tyrosine kinase and the paxillin adaptor protein, and subsequent binding of phosphorylated-paxillin to the CD103 cytoplasmic domain, initiating outside-in signaling that promotes $\mathrm{CD}^{+}$ $\mathrm{T}_{\mathrm{RM}}$ migratory behavior and effector functions [63].

\section{Tumor $T_{R M}$ cells are endowed with cytotoxicity potential}

Lung $\mathrm{T}_{\mathrm{RM}}$ cells display high expression levels of mRNA encoding effector molecules, such as granzyme B, IFN- $\gamma$ and TNF, without the need for ex vivo stimulation [14]. In human lung tumors, $\mathrm{CD}^{+} \mathrm{CD} 103^{+} \mathrm{T}_{\mathrm{RM}}$ cells were also found to express mRNA encoding molecules associated with cytotoxic activities of killer cells, such as IFNG, GZMA, GZMB and RAB27A [27, 38, 64]. Expression by $\mathrm{CD} 8^{+} \mathrm{CD} 103^{+}$TIL of granzyme $\mathrm{B}$, perforin and the degranulation marker LAMP-1 (CD107a) was confirmed at the protein level, further supporting their cytotoxic potential [27, 38, 64]. Moreover, in ovarian and lung cancer, $\mathrm{T}_{\mathrm{RM}}$ cells express the activation marker HLA-DR and the proliferation marker Ki67 [38, 64]. These cells may be functionally exhausted within the tumor microenvironment by the induction of T-cell inhibitory receptors including PD-1 and Tim-3 [27].

Priming of $T_{R M}$ cells in normal and tumoral tissues $\mathrm{T}_{\mathrm{RM}}$ cells are part of the adaptive immune system. Thus, their induction requires previous contact with antigenic peptide-MHC-I (pMHC-I) complexes following presentation of the antigen by antigen-presenting cells (APC). Notably, only particular subpopulations of DC (Batf3-dependent DC in mice, CD1c ${ }^{+}$TGF- $\beta$-producing DC in human) have the ability to generate $\mathrm{T}_{\mathrm{RM}}$ cells $[10,65]$. The specificity of $T_{R M}$ cells compared to other $T$ cells resides in the differentiation cues after initial activation, which leads to expression of markers involved in T-cell residency and persistence in the tissue, such as CD103, CD49a and $\alpha_{4} \beta_{7}$ [66]. Indeed, it has been shown by several groups that neutralization of $\mathrm{T}_{\mathrm{RM}}$ cell markers by blocking antibodies toward CD49a or CD103, or the absence of $\alpha_{4} \beta_{7}$ integrin in $\alpha_{4} \beta_{7}$-deficient cells, hampers the presence and persistence of $T_{R M}$ in tissues [36, 37, 67], suggesting a crucial role for these molecules in the development of $\mathrm{T}_{\mathrm{RM}}$.

Cytokines present in tissues also contribute to induction of $\mathrm{T}_{\mathrm{RM}}$ residency markers. As mentioned above, TGF- $\beta$, a cytokine produced by immune and epithelial cells, drives CD103 expression. In this context, inhibition of TGF- $\beta$ by neutralizing antibodies or inactivation of its receptor on $\mathrm{CD}^{+} \mathrm{T}$ cells results in a decrease in $\mathrm{CD} 8{ }^{+} \mathrm{CD} 103^{+} \mathrm{T}$-cell number in the specific tissue [39]. Depending on their location in the skin, salivary gland or kidney, $\mathrm{T}_{\mathrm{RM}}$ cells require IL-15 for their persistence, likely due to the role of this interleukin in upregulation of CD103; but this does not seem to be the case in genital or small intestine tissues [37, 48, 68]. Furthermore, other environmental cues driven by retinoic acid or the pro-inflammatory cytokines IL-2, IL-12, IL-18 and IL-33, might also be essential, parallel to TCR activation, for development of the $T_{R M}$ phenotype [17]. Various cells can secrete these molecules, including APC, stroma cells and epithelial cells. Consequently, the phenotype of $T_{R M}$ depends on the cytokine profile present in each histological zone and, concomitantly, on secreting cells that infiltrate tissues [69], which may explain $\mathrm{T}_{\mathrm{RM}}$ phenotypic diversity in the organism. Despite enhancing the formation of memory $\mathrm{CD}^{+} \mathrm{T}$ cells in secondary lymphoid tissues, rapamycin, an inhibitor of the mTor pathway, blocks the formation of resident memory $\mathrm{CD} 8^{+} \mathrm{T}$ cells in intestinal and vaginal mucosa. The ability of rapamycin to inhibit the formation of functional resident $\mathrm{CD} 8^{+}$ $\mathrm{T}$ cells in mucosal tissues protected mice from a $\mathrm{CD} 8^{+}$ T-cell-mediated lethal intestinal autoimmunity [70].

The role of cognate antigen in the priming of $T_{R M}$ cells is a matter of debate, as in the lung and brain, this antigenic contact is mandatory $[19,71]$. However, topical application of the skin irritant DNFB (2,4-dinitrofluorobenzene) or a local application of cytokines in the genital tract after systemic priming were sufficient for local generation and/or recruitment of $\mathrm{T}$ cells with a $\mathrm{T}_{\mathrm{RM}}$ phenotype $[72,73]$. In parallel with the molecular description, it has been shown that some vaccination strategies preferentially lead to induction of $\mathrm{T}_{\mathrm{RM}}$ cells. Indeed, mucosal, but not systemic, routes (intramuscular), generate a potent local T-cell response with a $T_{R M}$ phenotype, in parallel with a systemic response. For example, multiple studies, 
especially in an infectious context, have shown that tissue-specific vaccination is more effective at generating local immunity and $\mathrm{T}_{\mathrm{RM}}$ cells at barrier sites because it favors homing of immune cells to local sites [74]. In the same manner, heterologous prime-boost strategy with a cervico-vaginal boost enhances the establishment of specific $\mathrm{CD}^{+} \mathrm{T}$ cells expressing $\alpha_{4} \beta_{7}$ integrin in the genital tract compared to an intramuscular boost [67]. In the human papillomavirus (HPV) subtype 16 E7 vaccine model, an intranasal, but not an intramuscular vaccine, promotes specific infiltration of $\mathrm{CD} 103^{+} \mathrm{CD} 49 \mathrm{a}^{+} \mathrm{CD} 8^{+}$ $\mathrm{T}$ cells in broncho-alveolar lavage and also in an HPV16-E7-expressing tongue tumor [36]. The advantage of site-specific vaccination compared to systemic immunization for inducing local immunity and $T_{R M}$ cells could be explained by imprinting of $\mathrm{T}$ cells induced after initial activation by tissue APC. Indeed, specific DC have been shown to be involved in upregulation of specific molecular homing programs on $\mathrm{T}$ cells. Along the same lines, lung but not splenic DC were able to drive CD49a expression in vitro after intranasal vaccination of OT-I mice [36]. At present, DC seem to provide differentiation and homing signals to the initial site of priming through production of specific cytokines. This is supported by the observation that local DC induce $\alpha_{4} \beta_{7}$ on $\mathrm{CD}^{+} \mathrm{T}$ cells through their secretion of retinoic acid after a cervico-vaginal boost [67]. Similarly, respiratory $\mathrm{CD}_{103}{ }^{+} \mathrm{DC}$ promote $\mathrm{CD} 103$ upregulation upon $\mathrm{CD}^{+}$T-cell activation in a TGF- $\beta$-dependent manner [75]. In a virus model, Iborra et al. also demonstrated that DNGR-1 $1^{+}$(Clec9a) DC provide essential cytokine signals for the development of a $\mathrm{T}_{\mathrm{RM}}$ phenotype [76]. Overall, the molecular mechanisms involved in $\mathrm{T}_{\mathrm{RM}}$ priming are highly complex due to the wide diversity of experimental models, tissues, cells and markers studied with no standardization. It appears that DC and the tissue microenvironment are both implicated in the induction of a particular $\mathrm{T}_{\mathrm{RM}}$ phenotype. Future studies should define the coordinated role of the various parameters (DC, cytokines, stroma signals and sequences of the various steps) in generating $\mathrm{T}_{\mathrm{RM}}$. Such insights may help to better understand how to prime these memory $\mathrm{T}$ cells.

\section{Role of $T_{R M}$ in immune surveillance and immunotherapy}

\section{$T_{R M}$ cells can be located in solid tumors}

Mueller and Mackay [77] revealed that $\mathrm{T}_{\mathrm{RM}}$ cells are mainly present in non-lymphoid tissues and express CD69 and the CD103 integrin. These cells are also found in various tumors, including melanoma [78], lung cancer [27, 39], urothelial cell carcinoma [29] and endometrial adenocarcinoma [79]. Tumors with a high density of $\mathrm{CD}^{+} \mathrm{T}$ cells showed enrichment for transcripts linked to tissue-T-cell-residency, such as CD103
[38]. However, there exists phenotypic heterogeneity in $\mathrm{T}_{\mathrm{RM}}$ cells according to their location and tumor histological subtype. In all subtypes of endometrial adenocarcinoma, $\mathrm{CD}^{+}$TIL were present in both the tumor epithelium and stromal areas, but the frequency of $\mathrm{CD} 8^{+} \mathrm{CD} 103^{+} \mathrm{T}$ cells was significantly higher in the tumor epithelium than in the stroma $[27,29,79]$. Most $\mathrm{CD}_{103^{+}}$cells in the tumor microenvironment co-express the CD8 molecule, whereas $\mathrm{CD}^{+}$TIL located in the stroma were mainly negative for CD103 integrin. Nizard et al. found that $70 \%$ of intra-tumoral $\mathrm{CD}^{+} \mathrm{T}$ cells expressed CD103, whereas the integrin is found on only $41 \%$ of stromal $\mathrm{CD}^{+} \mathrm{T}$ cells [39]. Conversely, $\mathrm{CD}^{+} 03^{+}$cells in the healthy endometrium were negative for $\mathrm{CD} 3$ and CD16, suggesting a non-T-cell origin [29].

CD103 binds to E-cadherin expressed on the surface of epithelial cells [52]; this binding may be involved in retention of these cells in the epithelial tissue, as well as in solid tumors [80]. Interestingly, in some studies, distribution of $\mathrm{CD} 103^{+}$TIL was positively associated with E-cadherin expression on tumor cells [29]. However, in other studies, there was no obvious correlation between E-cadherin staining intensity and the presence of $\mathrm{CD}_{103^{+}} \mathrm{TIL}$, suggesting that other factors are also determinant in their infiltration $[26,81]$.

\section{$\mathrm{T}_{\mathrm{RM}}$ cells control tumor growth}

In a preclinical model of spontaneous breast cancer, a natural immune response involving resident innate lymphoid cells (ILC) close to ILC1 and TCR-positive cells was described [82]. These cells do not recirculate and delay tumor growth. Tumor growth control can be explained by the fact that $\mathrm{CD} 49 \mathrm{a}^{+}$and $\mathrm{CD} 103^{+}$cells are highly activated and exhibit more satisfactory effector functions than conventional $\mathrm{CD}^{+} \mathrm{T}$ cells $[27,38,83]$. These resident cells produce more IFN- $\gamma$ and granzyme $B$ than their integrin-negative counterparts. Accordingly, significantly impaired tumor control was observed in mice treated with either anti-CD49a or anti-CD103 antibodies [36, 83].

Following vaccination against orthotopic tumors, it has been shown that $T_{R M}$ cells are required for the efficacy of a cancer vaccine. Indeed, in a preclinical head and neck cancer model expressing E6-E7 proteins from HPV, the mucosal (intranasal) delivery of a vaccine (the $B$ subunit of Shiga toxin coupled with the E7 protein from HPV16) was efficient at eliciting local $\mathrm{T}_{\mathrm{RM}}$ cells and control of tumor growth [36]. Interestingly, a body of experiments demonstrated the role of $\mathrm{T}_{\mathrm{RM}}$ cells in the efficacy of this cancer vaccine. Indeed, depletion of $\mathrm{CD}_{49 \mathrm{a}^{+}} \mathrm{T}_{\mathrm{RM}}$ cells with an antibody hampered infiltration of $\mathrm{T}_{\mathrm{RM}}$ in mucosal tumors and partially inhibited the efficacy of intranasal vaccination to control mucosal tongue tumors. Similar results were obtained by Murray et al., using anti-CD49a mAb in 
a melanoma model [83]. In one of our group's study, the co-administration of an anti-TGF- $\beta$ antibody with the vaccine reduced the number of $\mathrm{T}_{\mathrm{RM}}$ cells and control of tumor growth by the vaccine [39]. By blocking recruitment of effector $\mathrm{T}$ cells arising from the lymphoid organs with the FTY720 drug, which downmodulates the S1PR1 molecule, it has been demonstrated that $\mathrm{T}_{\mathrm{RM}}$ cells induced by intranasal vaccination are able to control tumors [39]. Lastly, in a parabiosis mouse model, one of our groups showed that $\mathrm{T}_{\mathrm{RM}}$ cells induced by intranasal vaccination are required to control orthotopic head and neck tumor growth [39]. These results obtained with parabiosis experiments have been reproduced by the group of Sancho [10]. Together, these observations suggest that the absence of local $\mathrm{T}_{\mathrm{RM}}$ induction correlates with lower vaccine efficiency; they highlight the crucial role of these cells in tumor control. In line with these results, it was reported that cervico-vaginal boost with an HPV vaccine after a systemic (intramuscular) prime was more efficient at eliciting local cervical $\mathrm{T}_{\mathrm{RM}}$ cells, which was correlated with better mouse survival than that observed with an intramuscular boost [67]. In another model, it was shown that the number of $T_{R M}$ cells in tissues gradually increased after each boost [20], underlining the need for repeated injections.

At the present time, anti-tumor vaccine protocols almost exclusively use systemic administration with no significant clinical results, whereas various cancers are located in mucosal sites (lung, head and neck and urogenital). Therefore, it is important to reevaluate the advantage of local delivery by better understanding $\mathrm{T}_{\mathrm{RM}}$ cell physiology [84]. It should be mentioned that other non- $\mathrm{T}_{\mathrm{RM}}$ effector cells might also play a role in control of mucosal tumors [85], and the presence of $T_{R M}$ is not always sufficient to cure high grade cervical dysplasia after vaccination, likely due to the presence of immunosuppressive mechanisms or their insufficient local number [86].

\section{Prognostic value of $T_{R M}$ cells}

The $\mathrm{CD}^{+} \mathrm{T}_{\mathrm{RM}}$ subset has emerged as a predictive marker of survival in several human epithelial cancers $[26,27,29,38,87]$. In this regard, one of our groups first demonstrated that an enhanced CD103 ${ }^{+}$TIL subset correlates with improved early-stage non-small-cell lung carcinoma (NSCLC) patient survival [27]. The predictive value of $\mathrm{T}_{\mathrm{RM}}$ was also demonstrated in ovarian, breast and bladder cancers $[26,28,64,88]$. Indeed, in a large cohort of high-grade serous ovarian cancers, $\mathrm{CD} 103^{+}$ TIL were associated with improved patient survival [26]. Moreover, the expression of CD103 on TIL was associated with improved overall and recurrence-free survival in a retrospective cohort of urothelial cell carcinoma patients [29]. This integrin also appeared to be a biomarker of favorable prognosis in a large cohort of breast cancer patients [89]. However, the CD103 biomarker could also be expressed by $\mathrm{CD} 4^{+} \mathrm{T}$ cells and $\mathrm{DC}$, which introduces bias in interpretation of results without double immunostaining with anti-CD8 $\mathrm{mAb}$. The epithelial location of $\mathrm{CD}_{103}{ }^{+}$TIL is an even more significant prognosis marker compared to the stromal location, suggesting that intraepithelial $\mathrm{CD}^{+} \mathrm{CD}_{103^{+}}$cells encompass a higher proportion of tumor-specific $\mathrm{T}_{\mathrm{RM}}$ cells $[27,89]$. This intratumoral infiltration of $\mathrm{CD}_{103^{+}}$TIL was associated with expression of E-cadherin on tumor cells in bladder cancer [29], but not in ovarian or breast cancer [26, 89].

Since it is well known that $\mathrm{CD}^{+}{ }^{+}$-cell infiltration is associated with better clinical outcome in many cancers [90], comparative analysis of the prognostic value of $\mathrm{T}_{\mathrm{RM}}$ and $\mathrm{CD}^{+} \mathrm{T}$ cells has been lacking. Two recent studies, including one from one of our groups, demonstrated that, in two independent cohorts of lung cancer patients, $T_{R M}$ cells were correlated with patient survival in both univariate and multivariate analysis, and this effect was independent of $\mathrm{CD} 8^{+} \mathrm{T}$ cells $[38,39]$.

\section{$\mathrm{T}_{\mathrm{RM}}$ in adoptive cell transfer therapy}

With respect to adoptive cell transfer, Milner et al., identified the transcription factor Runx3 as critical for the establishment of $\mathrm{T}_{\mathrm{RM}}$ cell populations in various normal tissues and in cancer [15]. In a preclinical model of melanoma, adoptive transfer of $\mathrm{CD}^{+}$TIL lacking expression of Runx3 and which did not exhibit a $T_{R M}$ cell phenotype resulted in uncontrolled tumor growth and low animal survival. In contrast, when anti-tumor $\mathrm{CD} 8^{+}$ $\mathrm{T}$ cells overexpressing Runx3 were transferred in vivo, tumor growth was inhibited, and mouse survival improved [15]. Thus, adoptive cell therapy with anti-tumor $\mathrm{CD}^{+}$tumor-infiltrating $\mathrm{T}$ lymphocytes displaying a $\mathrm{T}_{\mathrm{RM}}$ phenotype improves the efficacy of this immunotherapy approach. Although $\mathrm{T}_{\mathrm{RM}}$ cells lacking the expression of CD103 integrin have been observed, the transfer of CD103-deficient $\mathrm{T}$ cells has also been used to demonstrate the role of $\mathrm{T}_{\mathrm{RM}}$ cells in tumor progression control. In this setting, it has been shown that $T_{R M}$ cells are required for animal protection [78].

\section{$T_{R M}$ cells are potential effectors of checkpoint blockade immunotherapy}

One of our groups was the first to report preferential expression of immune checkpoint receptors (PD-1 and TIM-3) and costimulatory molecules (ICOS) in $\mathrm{T}_{\mathrm{RM}}$ cells from lung cancer patients [27], extending similar results observed in $\mathrm{T}_{\mathrm{RM}}$ from normal tissues [37, 91]. These results have been confirmed in other cancers, both in mice and in humans $[27,38,39,83,92]$. In human cervical cancer, a strong correlation between expression of CD103 and exhaustion molecules such as PD-1, TIGIT, LAG-3 and Tim-3 has been observed using the Cancer 
Genome Atlas [93]. This result has been confirmed at the protein level in ovarian and endometrial adenocarcinomas $[26,79]$. Other checkpoint receptors (NKG2A, CD39, adenosine receptor A2AR and SPRY1) may also be preferentially expressed by $T_{R M}$ cells $[14,38]$. Remarkably, one of our groups showed that blockade of PD- 1 on $\mathrm{T}_{\mathrm{RM}}$ cells freshly isolated from human lung carcinomas strongly promotes cytolytic activity toward autologous tumor cells ex vivo [27]. Moreover, anti-MHC-I and anti-CD103 neutralizing antibodies dramatically inhibited target cell killing by autologous TIL pretreated with anti-PD-1, further emphasizing that $\mathrm{CD} 8^{+} \mathrm{CD} 103^{+} \mathrm{T}_{\mathrm{RM}}$ cells were exhausted tumor-specific $\mathrm{T}$ lymphocytes, which could be rescued by blocking PD-1 signals resulting in T-cell activation and autologous tumor cell killing [27]. In line with these results, after infection in mucosal tissues, $\mathrm{T}_{\mathrm{RM}}$ cells can proliferate and generate a second pool of $\mathrm{T}_{\mathrm{RM}}$, strongly suggesting that they have the ability to be activated in situ for better control of local danger [94]. Therefore, their exhausted phenotype does not preclude their sensitivity to reactivation and invigoration [95]. Consistently, recent results revealed expansion of $\mathrm{T}_{\mathrm{RM}}$ cells in melanoma patients responding to anti-PD-1 immunotherapy [96].

Taken together, their expression of checkpoint receptors, their strategic location in close tumor contact and their ability to proliferate in situ after a local stimulus suggest that $\mathrm{T}_{\mathrm{RM}}$ cells are enriched in tumor-specific $\mathrm{CD} 8^{+} \mathrm{T}$ cells, making them possible effectors of anti-PD-1/anti-PD-L1 cancer immunotherapy.

\section{Conclusion}

Overall, $\mathrm{T}_{\mathrm{RM}}$ cells appear to represent important components in cancer immunology. Their presence in the tumor microenvironment is correlated with good clinical outcome and may identify spontaneously immunogenic tumors. Moreover, their induction by cancer vaccines or other immunotherapeutic approaches may be critical for the success of immunotherapy. Several arguments strongly suggest that they may be the target of anti-PD-1/PD-L1 $\mathrm{mAb}$ therapies in various human cancers.

\section{Funding}

ANR-15-CE17-0023-04 (Selectimmuno) (E.T.), Labex Immuno-Oncology (E.T.), SIRIC CARPEM (E.T., CG), SIRIC SOCRATE (FMC, SC), INCA 2016-1 PL Bio-05 (FMC, ET), Association pour la Recherche sur le Cancer (ARC) and Groupement des Entreprises Françaises de Lutte contre le Cancer (GEFLUC). SC is a recipient of a fellowship from INCa.

\section{Authors' contributions}

FM-C and ET coordinated the writing of the manuscript. CB, SC, SH, IM, CG, IT participated in drafting and editing the text and figure. All authors gave final approval to the version submitted.

Ethics approval and consent to participate Not applicable
Consent for publication

Not applicable

\section{Competing interests}

The authors declare that they have no competing interests.

\section{Publisher's Note}

Springer Nature remains neutral with regard to jurisdictional claims in published maps and institutional affiliations.

\section{Author details}

${ }^{1}$ INSERM UMR 1186, Integrative Tumor Immunology and Genetic Oncology, Gustave Roussy, EPHE, PSL, Faculté de Médecine, University Paris-Sud, Université Paris-Saclay, 39, rue Camille Desmoulins, F-94805 Villejuif, France. ${ }^{2}$ INSERM U970, Universite Paris Descartes, Paris, France. ${ }^{3}$ Hôpital européen Georges Pompidou. Service d'Immunologie biologique, 20, Rue Leblanc, 75015 Paris, France. ${ }^{4}$ Equipe labellisée Ligue contre le Cancer, Paris, France.

Received: 11 May 2018 Accepted: 16 August 2018

Published online: 04 September 2018

\section{References}

1. Masopust $D$, Vezys $V$, Marzo AL, Lefrancois L. Preferential localization of effector memory cells in nonlymphoid tissue. Science. 2001;291:2413-7.

2. Hogan RJ, Zhong W, Usherwood EJ, Cookenham T, Roberts AD, Woodland $\mathrm{DL}$. Protection from respiratory virus infections can be mediated by antigenspecific CD4(+) T cells that persist in the lungs. J Exp Med. 2001;193:981-6.

3. Gebhardt T, Wakim LM, Eidsmo L, Reading PC, Heath WR, Carbone FR. Memory $T$ cells in nonlymphoid tissue that provide enhanced local immunity during infection with herpes simplex virus. Nature Immunol. 2009; 10:524-30.

4. Wakim LM, Waithman J, van Rooijen N, Heath WR, Carbone FR. Dendritic cell-induced memory $T$ cell activation in nonlymphoid tissues. Science. 2008:319:198-202

5. Woodberry T, Suscovich TJ, Henry LM, August M, Waring MT, Kaur A, et al. Alpha E beta 7 (CD103) expression identifies a highly active, tonsil-resident effector-memory CTL population. J Immunol. 2005;175:4355-62.

6. Clark RA, Chong B, Mirchandani N, Brinster NK, Yamanaka K, Dowgiert RK, et al. The vast majority of CLA+ T cells are resident in normal skin. J Immunol. 2006:176:4431-9.

7. Klonowski KD, Williams KJ, Marzo AL, Blair DA, Lingenheld EG, Lefrancois L. Dynamics of blood-borne CD8 memory $T$ cell migration in vivo. Immunity. 2004:20:551-62.

8. Masopust D, Choo D, Vezys V, Wherry EJ, Duraiswamy J, Akondy R, et al. Dynamic $T$ cell migration program provides resident memory within intestinal epithelium. J Exp Med. 2010;207:553-64.

9. Steinert EM, Schenkel JM, Fraser KA, Beura LK, Manlove LS, Igyarto BZ, et al. Quantifying Memory CD8 T Cells Reveals Regionalization of Immunosurveillance. Cell. 2015;161:737-49.

10. Enamorado M, Iborra S, Priego E, Cueto FJ, Quintana JA, Martinez-Cano S, et al. Enhanced anti-tumour immunity requires the interplay between resident and circulating memory CD8(+) T cells. Nature Comm. 2017:8:16073.

11. Intlekofer AM, Takemoto N, Wherry EJ, Longworth SA, Northrup JT, Palanivel VR, et al. Effector and memory CD8+ T cell fate coupled by T-bet and eomesodermin. Nature Immunol. 2005;6:1236-44.

12. Zhou X, Yu S, Zhao DM, Harty JT, Badovinac VP, Xue HH. Differentiation and persistence of memory CD8(+) T cells depend on T cell factor 1. Immunity. 2010:33:229-40.

13. Mackay LK, Minnich M, Kragten NA, Liao Y, Nota B, Seillet C, et al. Hobit and Blimp1 instruct a universal transcriptional program of tissue residency in lymphocytes. Science. 2016;352:459-63.

14. Hombrink P, Helbig C, Backer RA, Piet B, Oja AE, Stark R, et al. Programs for the persistence, vigilance and control of human CD8+ lung-resident memory T cells. Nature Immunol. 2016;17:1467-78.

15. Milner JJ, Toma C, Yu B, Zhang K, Omilusik K, Phan AT, et al. Runx3 programs CD8(+) T cell residency in non-lymphoid tissues and tumours. Nature. 2017:552:253-7.

16. Casey KA, Fraser KA, Schenkel JM, Moran A, Abt MC, Beura LK, et al. Antigen-independent differentiation and maintenance of effector-like resident memory T cells in tissues. J Immunol. 2012;188:4866-75. 
17. Skon CN, Lee JY, Anderson KG, Masopust D, Hogquist KA, Jameson SC Transcriptional downregulation of $\mathrm{S} 1 \mathrm{pr} 1$ is required for the establishment of resident memory CD8+ T cells. Nature Immunol. 2013; 14:1285-93.

18. Zhang N, Bevan MJ. Transforming growth factor-beta signaling controls the formation and maintenance of gut-resident memory $T$ cells by regulating migration and retention. Immunity. 2013;39:687-96.

19. Wakim LM, Woodward-Davis A, Bevan MJ. Memory T cells persisting within the brain after local infection show functional adaptations to their tissue of residence. Proc Natl Acad Sci U S A. 2010;107:17872-9.

20. Jiang X, Clark RA, Liu L, Wagers AJ, Fuhlbrigge RC, Kupper TS. Skin infection generates non-migratory memory CD8+ T(RM) cells providing global skin immunity. Nature. 2012;483:227-31.

21. Piet B, de Bree GJ, Smids-Dierdorp BS, van der Loos CM, Remmerswaal EB, von der Thusen JH, et al. CD8(+) T cells with an intraepithelial phenotype upregulate cytotoxic function upon influenza infection in human lung. J Clin Invest. 2011;121:2254-63.

22. Mackay LK, Stock AT, Ma JZ, Jones CM, Kent SJ, Mueller SN, et al. Long-lived epithelial immunity by tissue-resident memory T (TRM) cells in the absence of persisting local antigen presentation. Proc Natl Acad Sci U S A. 2012;109: 7037-42.

23. Wagner N, Lohler J, Kunkel EJ, Ley K, Leung E, Krissansen G, et al. Critical role for beta7 integrins in formation of the gut-associated lymphoid tissue. Nature. 1996;382:366-70.

24. Lefrancois L, Parker CM, Olson S, Muller W, Wagner N, Schon MP, et al. The role of beta7 integrins in CD8 T cell trafficking during an antiviral immune response. J Exp Med. 1999;189:1631-8.

25. Schon MP, Arya A, Murphy EA, Adams CM, Strauch UG, Agace WW, et al. Mucosal T lymphocyte numbers are selectively reduced in integrin alpha $\mathrm{E}$ (CD103)-deficient mice. J Immunol. 1999:162:6641-9.

26. Webb JR, Milne K, Watson P, Deleeuw RJ, Nelson BH. Tumor-infiltrating lymphocytes expressing the tissue resident memory marker CD103 are associated with increased survival in high-grade serous ovarian cancer. Clin Cancer Res. 2014;20:434-44.

27. Djenidi F, Adam J, Goubar A, Durgeau A, Meurice G, de Montpreville V, et al. CD8+CD103+ tumor-infiltrating lymphocytes are tumor-specific tissueresident memory $T$ cells and a prognostic factor for survival in lung cancer patients. J Immunol. 2015;194:3475-86.

28. Quinn E, Hawkins N, Yip YL, Suter C, Ward R. CD103+ intraepithelial lymphocytes--a unique population in microsatellite unstable sporadic colorectal cancer. Eur J Cancer. 2003;39:469-75.

29. Wang B, Wu S, Zeng H, Liu Z, Dong W, He W, et al. CD103+ Tumor Infiltrating Lymphocytes Predict a Favorable Prognosis in Urothelial Cell Carcinoma of the Bladder. J Urol. 2015;194:556-62.

30. Salmon H, Franciszkiewicz K, Damotte D, Dieu-Nosjean MC, Validire P, Trautmann A, et al. Matrix architecture defines the preferential localization and migration of T cells into the stroma of human lung tumors. J Clin Invest. 2012;122:899-910

31. Boutet M, Gauthier L, Leclerc M, Gros G, de Montpreville V, Theret N, et al. TGFbeta Signaling Intersects with CD103 Integrin Signaling to Promote T-Lymphocyte Accumulation and Antitumor Activity in the Lung Tumor Microenvironment. Cancer Res. 2016;76:1757-69.

32. Franciszkiewicz K, Le Floc'h A, Boutet M, Vergnon I, Schmitt A, MamiChouaib F. CD103 or LFA-1 engagement at the immune synapse between cytotoxic $T$ cells and tumor cells promotes maturation and regulates T-cell effector functions. Cancer Res. 2013;73:617-28.

33. Franciszkiewicz K, Le Floc'h A, Jalil A, Vigant F, Robert T, Vergnon I, et al. Intratumoral induction of CD103 triggers tumor-specific CTL function and CCR5-dependent T-cell retention. Cancer Res. 2009;69:6249-55.

34. Ray SJ, Franki SN, Pierce RH, Dimitrova S, Koteliansky V, Sprague AG, et al. The collagen binding alpha1 beta1 integrin VLA-1 regulates CD8 T cellmediated immune protection against heterologous influenza infection. Immunity. 2004;20:167-79.

35. lijima N, Iwasaki A. Tissue instruction for migration and retention of TRM cells. Trends Immunol. 2015;36:556-64.

36. Sandoval F, Terme M, Nizard M, Badoual C, Bureau MF, Freyburger L, et al. Mucosal Imprinting of Vaccine-Induced CD8+ T Cells Is Crucial to Inhibit the Growth of Mucosal Tumors. Sci Transl Med. 2013;5:172ra20.

37. Mackay LK, Rahimpour A, Ma JZ, Collins N, Stock AT, Hafon ML, et al. The developmental pathway for CD103(+)CD8+ tissue-resident memory T cells of skin. Nature Immunol. 2013;14:1294-301.
38. Ganesan AP, Clarke J, Wood O, Garrido-Martin EM, Chee SJ, Mellows T, et al. Tissue-resident memory features are linked to the magnitude of cytotoxic $\mathrm{T}$ cell responses in human lung cancer. Nature Immunol. 2017;18(8):940-50.

39. Nizard M, Roussel H, Diniz MO, Karaki S, Tran T, Voron T, et al. Induction of resident memory $T$ cells enhances the efficacy of cancer vaccine. Nature Comm. 2017:8:15221.

40. Bergsbaken T, Bevan MJ. Proinflammatory microenvironments within the intestine regulate the differentiation of tissue-resident CD8(+) T cells responding to infection. Nature Immunol. 2015;16:406-14.

41. Bromley SK, Yan S, Tomura M, Kanagawa O, Luster AD. Recirculating memory $T$ cells are a unique subset of $C D 4+T$ cells with a distinct phenotype and migratory pattern. J Immunol. 2013;190:970-6.

42. Watanabe R, Gehad A, Yang C, Scott LL, Teague JE, Schlapbach C, et al. Human skin is protected by four functionally and phenotypically discrete populations of resident and recirculating memory T cells. Sci Transl Med. 2015;7:279ra39.

43. Amsen D, van Gisbergen K, Hombrink P, van Lier RAW. Tissue-resident memory $T$ cells at the center of immunity to solid tumors. Nature Immunol. 2018;19:538-46.

44. Wang C, Thangamani S, Kim M, Gu BH, Lee JH, Taparowsky EJ, et al. BATF is required for normal expression of gut-homing receptors by $T$ helper cells in response to retinoic acid. J Exp Med. 2013;210:475-89.

45. Li Y, Innocentin S, Withers DR, Roberts NA, Gallagher AR, Grigorieva EF, et al. Exogenous stimuli maintain intraepithelial lymphocytes via aryl hydrocarbon receptor activation. Cell. 2011;147:629-40

46. Kurachi M, Barnitz RA, Yosef N, Odorizzi PM, Dilorio MA, Lemieux ME, et al. The transcription factor BATF operates as an essential differentiation checkpoint in early effector CD8+ T cells. Nature Immunol. 2014;15:373-83.

47. Xin G, Schauder DM, Lainez B, Weinstein JS, Dai Z, Chen Y, et al. A Critical Role of IL-21-Induced BATF in Sustaining CD8-T-Cell-Mediated Chronic Viral Control. Cell reports. 2015;13:1118-24.

48. Mackay LK, Wynne-Jones E, Freestone D, Pellicci DG, Mielke LA, Newman DM, et al. T-box Transcription Factors Combine with the Cytokines TGF-beta and IL15 to Control Tissue-Resident Memory T Cell Fate. Immunity. 2015:43:1101-11.

49. Zens KD, Chen JK, Guyer RS, Wu FL, Cvetkovski F, Miron M, et al. Reduced generation of lung tissue-resident memory $T$ cells during infancy. J Exp Med. 2017;214:2915-32.

50. Connors TJ, Baird JS, Yopes MC, Zens KD, Pethe K, Ravindranath TM, et al. Developmental Regulation of Effector and Resident Memory T Cell Generation during Pediatric Viral Respiratory Tract Infection. J Immunol. 2018; pii: ji1800396

51. Wolkers MC, Gerlach C, Arens R, Janssen EM, Fitzgerald P, Schumacher TN et al. Nab2 regulates secondary CD8+ T-cell responses through control of TRAIL expression. Blood. 2012;119:798-804.

52. Cepek KL, Shaw SK, Parker CM, Russell GJ, Morrow JS, Rimm DL, et al. Adhesion between epithelial cells and T lymphocytes mediated by Ecadherin and the alpha E beta 7 integrin. Nature. 1994;372:190-3.

53. Kilshaw PJ, Murant SJ. A new surface antigen on intraepithelial lymphocytes in the intestine. Eur J Immunol. 1990:20:2201-7.

54. Annacker O, Coombes JL, Malmstrom V, Uhlig HH, Bourne T, JohanssonLindbom B, et al. Essential role for CD103 in the T cell-mediated regulation of experimental colitis. J Exp Med. 2005;202:1051-61.

55. Rao PE, Petrone AL, Ponath PD. Differentiation and expansion of T cells with regulatory function from human peripheral lymphocytes by stimulation in the presence of TGF-\{beta\}. J Immunol. 2005:174:1446-55.

56. Cresswell J, Wong WK, Henry MJ, Robertson H, Neal DE, Kirby JA. Adhesion of lymphocytes to bladder cancer cells: the role of the alpha(E)beta(7) integrin. Cancer Immunol Immunother. 2002;51:483-91.

57. French JJ, Cresswell J, Wong WK, Seymour K, Charnley RM, Kirby JA. T cell adhesion and cytolysis of pancreatic cancer cells: a role for E-cadherin in immunotherapy? Brit J Cancer. 2002;87:1034-41.

58. Le Floc'h A, Jalil A, Vergnon I, Le Maux CB, Lazar V, Bismuth G, et al. Alpha E beta 7 integrin interaction with E-cadherin promotes antitumor CTL activity by triggering lytic granule polarization and exocytosis. J Exp Med. 2007;204:559-70.

59. Le Floc'h A, Jalii A, Franciszkiewicz K, Validire P, Vergnon I, Mami-Chouaib F. Minimal engagement of CD103 on cytotoxic T lymphocytes with an Ecadherin-Fc molecule triggers lytic granule polarization via a phospholipase Cgamma-dependent pathway. Cancer Res. 2011;71:328-38.

60. Mokrani M, Klibi J, Bluteau D, Bismuth G, Mami-Chouaib F. Smad and NFAT pathways cooperate to induce CD103 expression in human CD8 T lymphocytes. J Immunol. 2014;192:2471-9. 
61. Robinson PW, Green SJ, Carter C, Coadwell J, Kilshaw PJ. Studies on transcriptional regulation of the mucosal T-cell integrin alphaEbeta7 (CD103). Immunology. 2001;103:146-54.

62. Kinashi T. Intracellular signalling controlling integrin activation in lymphocytes. Nat Rev Immunol. 2005;5:546-59.

63. Gauthier L, Corgnac S, Boutet M, Gros G, Validire P, Bismuth G, et al. Paxillin Binding to the Cytoplasmic Domain of CD103 Promotes Cell Adhesion and Effector Functions for CD8(+) Resident Memory T Cells in Tumors. Cancer Res. 2017;77:7072-82.

64. Webb JR, Milne K, Nelson BH. PD-1 and CD103 Are Widely Coexpressed on Prognostically Favorable Intraepithelial CD8 T Cells in Human Ovarian Cancer. Cancer Immunol Res. 2015;3:926-35

65. Yu Cl, Becker C, Wang Y, Marches F, Helft J, Leboeuf M, et al. Human CD1C(+) Dendritic Cells Drive the Differentiation of CD103(+) CD8(+) Mucosal Effector T Cells via the Cytokine TGF-beta. Immunity. 2013;38:818-30.

66. Granier C, Blanc C, Karaki S, Tran T, Roussel H, Tartour E. Tissue-resident memory $T$ cells play a key role in the efficacy of cancer vaccines. Oncoimmunol. 2017;6 e1358841

67. Sun YY, Peng S, Han L, Qiu J, Song L, Tsai Y, et al. Local HPV Recombinant Vaccinia Boost Following Priming with an HPV DNA Vaccine Enhances Local HPV-Specific CD8+ T-cell-Mediated Tumor Control in the Genital Tract. Clin Cancer Res. 2016;22:657-69.

68. Schenkel JM, Fraser KA, Casey KA, Beura LK, Pauken KE, Vezys V, et al. IL-15Independent Maintenance of Tissue-Resident and Boosted Effector Memory CD8 T Cells. J Immunol. 2016;196:3920-6.

69. Yoshizawa A, Bi K, Keskin DB, Zhang G, Reinhold B, Reinherz EL. TCR-pMHC encounter differentially regulates transcriptomes of tissue-resident CD8 T cells. Eur J Immunol. 2018;48:128-50.

70. Sowell RT, Rogozinska M, Nelson CE, Vezys V, Marzo AL. Cutting edge: generation of effector cells that localize to mucosal tissues and form resident memory CD8 T cells is controlled by mTOR. J Immunol. 2014; 193:2067-71.

71. Takamura S, Yagi H, Hakata Y, Motozono C, McMaster SR, Masumoto T, et al. Specific niches for lung-resident memory CD8+ T cells at the site of tissue regeneration enable CD69-independent maintenance. J Exp Med. 2016;213: 3057-73.

72. Park SL, Zaid A, Hor JL, Christo SN, Prier JE, Davies B, et al. Local proliferation maintains a stable pool of tissue-resident memory $T$ cells after antiviral recall responses. Nature Immunol. 2018;19:183-91.

73. Shin $H$, Iwasaki A. A vaccine strategy that protects against genital herpes by establishing local memory T cells. Nature. 2012;491:463-7.

74. Nizard M, Roussel H, Tartour E. Resident Memory T Cells as Surrogate Markers of the Efficacy of Cancer Vaccines. Clin Cancer Res. 2016;22:530-2.

75. Wakim LM, Smith J, Caminschi I, Lahoud MH, Villadangos JA. Antibodytargeted vaccination to lung dendritic cells generates tissue-resident memory CD8 T cells that are highly protective against influenza virus infection. Mucosal Immunol. 2015:8:1060-71.

76. Iborra S, Martinez-Lopez M, Khouili SC, Enamorado M, Cueto FJ, CondeGarrosa R, et al. Optimal Generation of Tissue-Resident but Not Circulating Memory T Cells during Viral Infection Requires Crosspriming by DNGR-1(+) Dendritic Cells. Immunity. 2016;45:847-60.

77. Mueller SN, Mackay LK. Tissue-resident memory T cells: local specialists in immune defence. Nat Rev Immunol. 2016;16:79-89.

78. Malik BT, Byrne KT, Vella JL, Zhang P, Shabaneh TB, Steinberg SM, et al. Resident memory $T$ cells in the skin mediate durable immunity to melanoma. Sci Immunol. 2017;2(10)

79. Workel HH, Komdeur FL, Wouters MC, Plat A, Klip HG, Eggink FA, et al. CD103 defines intraepithelial CD8+ PD1+ tumour-infiltrating lymphocytes of prognostic significance in endometrial adenocarcinoma. Eur J Cancer. 2016;60:1-11.

80. Cepek KL, Parker CM, Madara JL, Brenner MB. Integrin alpha E beta 7 mediates adhesion of T lymphocytes to epithelial cells. J Immunol. 1993; 150:3459-70.

81. Cresswell J, Robertson H, Neal DE, Griffiths TR, Kirby JA. Distribution of lymphocytes of the alpha(E)beta(7) phenotype and E-cadherin in normal human urothelium and bladder carcinomas. Clin Exp Immunol. 2001;126: 397-402.

82. Dadi S, Chhangawala S, Whitlock BM, Franklin RA, Luo CT, Oh SA, et al Cancer Immunosurveillance by Tissue-Resident Innate Lymphoid Cells and Innate-like T Cells. Cell. 2016;164:365-77.
83. Murray T, Fuertes Marraco SA, Baumgaertner P, Bordry N, Cagnon L, Donda A, et al. Very Late Antigen-1 Marks Functional Tumor-Resident CD8 T Cells and Correlates with Survival of Melanoma Patients. Front Immunol. 2016;7:573.

84. Tartour E, Zitvogel L. Lung cancer : potential targets for immunotherapy. Lancet Respir Med. 2013;1:551-63.

85. Bialkowski $L$, van Weijnen A, Van der Jeught K, Renmans D, Daszkiewicz L, Heirman C, et al. Intralymphatic mRNA vaccine induces CD8 T-cell responses that inhibit the growth of mucosally located tumours. Sci Rep. 2016;6:22509.

86. Morrow MP, Kraynyak KA, Sylvester AJ, Dallas M, Knoblock D, Boyer JD, et al. Clinical and Immunologic Biomarkers for Histologic Regression of HighGrade Cervical Dysplasia and Clearance of HPV16 and HPV18 after Immunotherapy. Clin Cancer Res. 2018;24:276-94.

87. Koh J, Kim S, Kim MY, Go H, Jeon YK, Chung DH. Prognostic implications of intratumoral CD103+ tumor-infiltrating lymphocytes in pulmonary squamous cell carcinoma. Oncotarget. 2017:8:13762-9.

88. Jouanneau E, Black KL, Veiga L, Cordner R, Goverdhana S, Zhai Y, et al. Intrinsically de-sialylated CD103(+) CD8 T cells mediate beneficial antiglioma immune responses. Cancer Immunol Immunother. 2014;63:911-24.

89. Wang ZQ, Milne K, Derocher H, Webb JR, Nelson BH, Watson PH. CD103 and Intratumoral Immune Response in Breast Cancer. Clin Cancer Res. 2016:22:6290-7.

90. Fridman WH, Zitvogel L, Sautes-Fridman C, Kroemer G. The immune contexture in cancer prognosis and treatment. Nat Rev Clin Oncol. 2017; 14:717-34

91. Wakim LM, Woodward-Davis A, Liu R, Hu Y, Villadangos J, Smyth G, et al. The molecular signature of tissue resident memory CD8 T cells isolated from the brain. J Immunol. 2012;189:3462-71.

92. Boddupalli CS, Bar N, Kadaveru K, Krauthammer M, Pornputtapong N,

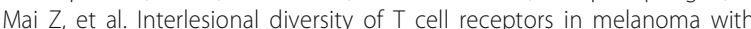
immune checkpoints enriched in tissue-resident memory T cells. JCl Insight. 2016;1 e88955

93. Komdeur FL, Prins TM, van de Wall S, Plat A, Wisman GBA, Hollema H, et al. CD103+ tumor-infiltrating lymphocytes are tumor-reactive intraepithelial CD8+ T cells associated with prognostic benefit and therapy response in cervical cancer. Oncoimmunol. 2017;6 e1338230

94. Low JS, Kaech SM. Trials and Tribble-ations of tissue TRM cells. Nature Immunol. 2018;19:102-3.

95. Granier C, Dariane C, Combe P, Verkarre V, Urien S, Badoual C, et al. Tim-3 Expression on Tumor-Infiltrating PD-1+CD8+ T Cells Correlates with Poor Clinical Outcome in Renal Cell Carcinoma. Cancer Res. 2017;77:1075-82.

96. Edwards J, Wilmott JS, Madore J, Gide TN, Quek C, Tasker A, et al. CD103(+) Tumor-Resident CD8(+) T Cells Are Associated with Improved Survival in Immunotherapy-Naive Melanoma Patients and Expand Significantly During Anti-PD-1 Treatment. Clin Cancer Res. 2018;24(13):3036-45.

\section{Ready to submit your research? Choose BMC and benefit from:}

- fast, convenient online submission

- thorough peer review by experienced researchers in your field

- rapid publication on acceptance

- support for research data, including large and complex data types

- gold Open Access which fosters wider collaboration and increased citations

- maximum visibility for your research: over $100 \mathrm{M}$ website views per year

At BMC, research is always in progress.

Learn more biomedcentral.com/submissions 